\title{
PROCESSOS GRUPAIS NO CINEMA: DOZE HOMENS E UMA SENTENÇA
}

\section{ARTIGO DE REVISÃo}

ABREU, Liliane Alcântara de 1, MELO, Natalia Sayuri 2, SOARES, Pamela Cristina ${ }^{3}$, CYPRIANO, Nathalia Gonçalves Domingues ${ }^{4}$, NUNES, Letícia Monteiro 5, SILVA, Gabriella Braga Dias da ${ }^{6}$, HAERTHEL, Susan Mara ${ }^{7}$, MENDES, Matheus Passos ${ }^{8}$

ABREU, Liliane Alcântara de. Et al. Processos grupais no cinema: doze homens e uma sentença. Revista Científica Multidisciplinar Núcleo do Conhecimento. Ano. 07, Ed. 01, Vol. 05, pp. 94-130. Janeiro de 2022. ISSN: 2448-0959, Link de acesso: https://www.nucleodoconhecimento.com.br/psicologia/processos-grupais

1 Especialista em Neurociência Pedagógica pela AVM Educacional/UCAM/RJ; especialista em Arteterapia em Educação e Saúde pela AVM Educacional/UCAM/RJ; especialista em Pesquisa de Comportamento e Consumo pela Faculdade SENAI CETIQT RJ; especialista em Artes Visuais pela UNESA/RJ; bacharela em Design pela Faculdade SENAI CETIQT RJ. Bacharelanda em Psicologia pela UNIP/SP.

${ }^{2}$ Bacharela em Comunicação Social pela Faculdade Casper Libero/SP. Bacharelanda em Psicologia pela UNIP/SP.

${ }^{3}$ Bacharelanda em Psicologia pela UNIP/SP.

${ }^{4}$ Bacharelanda em Psicologia pela UNIP/SP.

${ }^{5}$ Bacharelanda em Psicologia pela UNIP/SP.

${ }^{6}$ Bacharelanda em Psicologia pela UNIP/SP.

${ }^{7}$ Bacharelanda em Psicologia pela UNIP/SP.

${ }^{8}$ Bacharelando em Psicologia pela UNIP/SP.

RC: 105389

Disponível em: https://www.nucleodoconhecimento.com.br/psicologia/processos-grupais 


\section{RESUMO}

Este artigo teve o objetivo de abordar e analisar o filme "Doze homens e uma sentença" (LUMET, 1957), a partir das contribuições teóricas e de técnicas diferenciadas para dinâmica de grupo. Neste contexto, levantou-se a questão norteadora: indivíduos com diferenças socioculturais específicas e historicidades divergentes colaboram nos desenvolvimentos psicológicos em processos grupais? Assim, o objetivo geral se fundamentou em compreender diferentes técnicas de dinâmica de grupo e suas aplicabilidades. A hipótese firmou-se no pressuposto de que indivíduos com históricos antagônicos podem contribuir com suas diferentes vivências para a aplicabilidade das técnicas de dinâmica de grupos e amadurecimento dos sujeitos. Como metodologia, a pesquisa se amparou no ponto principal de observação e análise do filme "Doze homens e uma sentença" (LUMET, 1957) e a relação com a revisão teórica de estudiosos para refletir e analisar suas influências, baseando-se nos princípios dos fundamentos históricos, epistemológicos e técnicos das teorias sobre grupos. Sob essa ótica, necessitou-se fazer o reconhecimento dos processos psicológicos e comportamentais no contexto grupal e a compreensão da natureza dos grupos pelos processos psicológicos pertencentes ao filme. Como resultado e conclusões, compreendeu-se que a partir do cruzamento das teorizações com o dinâmica apresentada no filme, que, por mais diferenciados que esses olhares possam ser, a análise de grupos parte da premissa de que os processos grupais vão se transformando a partir das ações dos indivíduos, bem como de suas posições econômicas e culturais.

Palavras-chave: Cinema, Dinâmica, Grupos, Psicologia, Sociedade.

\section{INTRODUÇÃO}

A finalidade deste trabalho foi de analisar a Arte e os processos de dinâmica de grupo. Para tanto, o estudo feito no primeiro semestre (março a maio) de 2021, levou em RC: 105389

Disponível em: https://www.nucleodoconhecimento.com.br/psicologia/processos-grupais 
consideração os estudos de Kurt Lewin por meio de Mailhiot (2013), de Moreno através de Russo (2010), Schutz (1979; 1989) e Pichon-Rivière (2009) sob a perspectiva do filme "Doze homens e uma sentença" (LUMET, 1957).

Neste contexto, levantou-se a seguinte questão norteadora: indivíduos com diferenças socioculturais específicas e historicidades divergentes colaboram nos desenvolvimentos psicológicos em processos grupais?

Assim, o objetivo geral se fundamentou em entender diferentes técnicas de dinâmica de grupo e suas aplicabilidades. Como consequência, os objetivos específicos se estenderam em entender as teorias e como cada um dos autores - Lewin, Schutz, Moreno, Pichon-Rivière - trabalhavam com processos grupais; compreender como relações intergrupais discriminatórias e historicidade podem atuar em uma dinâmica de grupo, e encontrar no filme uma possível intervenção de cada um dos teóricos.

A partir disto, foi possível, portanto, observar os signos comportamentais que compõem a hipótese para análise dos sujeitos envolvidos na trama, e que se firmou no pressuposto de que indivíduos com históricos antagônicos podem contribuir com suas diferentes vivências para a aplicabilidade das técnicas de dinâmica de grupos e amadurecimento dos sujeitos. Desse ponto de vista, as dúvidas iniciais, sobre o filme foram se dissipando pela própria construção de narrativa muito clara.

Como metodologia, a pesquisa se fundamentou no ponto principal de observação e análise do filme "Doze homens e uma sentença" (LUMET, 1957) e o levantamento da revisão teórica desses estudiosos para refletir e analisar suas influências, baseandose nos princípios dos fundamentos históricos, epistemológicos e técnicos das teorias sobre grupos. Sob essa ótica, fez-se o reconhecimento dos processos psicológicos e comportamentais no contexto grupal e a compreensão da natureza dos grupos pelos processos psicológicos pertencentes ao filme.

RC: 105389

Disponível em: https://www.nucleodoconhecimento.com.br/psicologia/processos-grupais 
O grupo de oito alunos se subdividiu em quatro subequipes (com dois integrantes em cada equipe), sendo que cada uma ficou incumbida de observar e analisar com atenção em um único teórico, para que cada percepção fosse isenta da interferência dos outros autores aqui divididos em sessões. Assim, a indagação inicial de como o grupo identificaria a metodologia dos teóricos em questão neste estudo, foi simplificada. Assim, tornar-se-ia mais fácil compará-los e discutir suas práticas.

Portanto, ao iniciar a análise do filme, a equipe deste artigo concentrou-se não só na efetiva teorização partida inicialmente de Barreto (2014), e que permeia as sessões, mas buscou o embasamento em autores variados e distribuídos da seguinte forma:

Na sessão 2 deste artigo, que explica os processos grupais de uma maneira mais ampla, a teorização incluiu Aroldo Rodrigues, Eveline Assmar e Bernardo Jablonsky (2009), Silvia Lane (1989), Sueli Martins (2007), Maritza Montero (2010), Paulo Freire (2011), Emanuel Vieira e Verônica Ximenes (2008), e o breve apoio de Ludimilla Teixeira e Liliane Abreu (2021). Além disso, faz-se um resumo breve explicativo sobre o contexto do filme de Lumet (1957). Na sessão 3, sobre Kurt Lewin, o apoio foi encontrado em Gérald Mailhiot (2013) - também referenciado na sessão 2. Na sessão 4, referente a Moreno, a equipe se apoiou em Luis Russo (2010), Liliana Lima (2014), e, Maria da Penha Nery e Maria Inês Conceição (2005). Na sessão 5, William Schutz (1979; 1989) foi embasado por ele mesmo e por Linda Smircich e Gareth Morgan (1983). Na sessão 6, Enrique Pichon-Rivière (2009) fundamentou a si mesmo. Por fim, as considerações finais encerram este artigo.

\section{O CINEMA E AS BASES DOS PROCESSOS GRUPAIS}

Primeiramente será apresentado o objeto a ser analisado. O filme "Doze homens e uma sentença" (LUMET, 1957) retrata a história do julgamento em território estadunidense, de um jovem de 18 anos, porto-riquenho, que é acusado de ter assassinado o pai de forma brutal. Ademais, sabe-se através de doze jurados

RC: 105389

Disponível em: https://www.nucleodoconhecimento.com.br/psicologia/processos-grupais 
incumbidos de dar a sentença final ao réu, que o rapaz perdeu a mãe aos 8 anos e foi criado de maneira violenta pelo pai. Todos os dias ele era espancado, e numa dessas ocasiões, comprou uma faca, passou muitas horas fora de casa, e ao retornar de madrugada, o pai havia sido morto com uma arma idêntica à que ele havia adquirido. O réu não negou a aquisição e a intencionalidade, mas refuta ter assassinado o pai.

Os jurados, isolados numa sala quente e pequena, e com pressa de saírem de lá (não só pelo incômodo, mas também porque demonstravam inquietude para se divertirem, e igualmente banalizando todo o processo decisório), onze decidiram rapidamente que o jovem devia ser condenado (o que o levaria à morte pelo tipo de crime). Apenas um jurado refutou a decisão, pedindo ao restante dos homens que analisassem melhor os fatos além daquilo que Ihes fora apresentado. Cada um dos personagens era identificado da seguinte forma:

- Jurado 1. Assistente de treinador (presidente da mesa)

- Jurado 2. Bancário

- Jurado 3. Empresário de recados com problemas com o filho

- Jurado 4. Corretor de Wall Street

- Jurado 5. Homem de origem humilde, mas que ascendeu socialmente

- Jurado 6. Trabalhador braçal/pintor

- Jurado 7. Apostador de jogos

- Jurado 8. Arquiteto (o homem discordante da sentença de culpado)

- Jurado 9. Idoso

- Jurado 10. Empresário de transportes que estava resfriado

- Jurado 11. Joalheiro de origem europeia

- Jurado 12. Jovem publicitário vaidoso

Diante dessa listagem, cabe ressaltar que os doze homens eram de origens e status sociais diferenciados, mas todos tentavam de certa forma se apresentar equiparados socialmente, mas, evidentemente, alguns se destacavam mais. Assim, a pauta de

RC: 105389

Disponível em: https://www.nucleodoconhecimento.com.br/psicologia/processos-grupais 
preconceito e discriminação, e o jogo de poder entre maioria e minoria psicológica são explícitas e presentes na análise do filme. A condução do jurado 8 para que ocorra a dinâmica de grupo, e a mudança de pensamento de cada jurado até o convencimento dos doze, de que talvez eles condenassem um inocente à morte, foi outro ponto relevante. Baseando-se nessas três vertentes (preconceito e discriminação, maioria e minoria psicológica, e a dinâmica de grupo) é que esse trabalho se estrutura, já que essa triangulação é o que fomenta toda a narrativa do filme.

\subsection{PRECONCEITO E DISCRIMINAÇÃO}

Em um capítulo específico sobre preconceito, estereótipo e discriminação, os autores Rodrigues; Assmar e Jablonsky (2009) explicam o que são e como funcionam esses fatores de impacto nas relações sociais.

Atitudes e comportamentos são conceitos diferentes para a Psicologia Social. Da mesma forma, atitudes e pensamentos também são diferentes. As atitudes de uma pessoa são mutáveis, pois ela pode estudar e evoluir, produzindo novos entendimentos que mudam sua atitude diante de variados posicionamentos. Assim, quanto maior for o interesse investido pela pessoa no conteúdo atitudinal, maior será a correspondência entre atitude e comportamento. (Rodrigues; Assmar; Jablonsky, 2009)

As atitudes ajudam a lidar com o ambiente social e possuem várias funções como permitir a obtenção de recompensa e evitar o castigo; proteger a autoestima e se poupar de ansiedades e conflitos; ajuda a ordenar e assimilar informações complexas; possibilita a reflexão das próprias convicções e valores; estabelece a identidade social. (Rodrigues; Assmar; Jablonsky, 2009)

Esses fatores desencadeiam valores de cunho teórico (com ênfase em aspectos racionais, críticos, empíricos e busca da verdade), estéticos (preocupados com a beleza, com harmonia e formas), de praticidade (com ênfase em utilidade e RC: 105389

Disponível em: https://www.nucleodoconhecimento.com.br/psicologia/processos-grupais 
pragmatismo, dominância de enfoque de natureza econômica), de atividades sociais (com ênfase no altruísmo e filantropia), de poder (com ênfase em influência, dominância e exercício do poder em várias esferas), e na religião (com ênfase em aspectos transcendentes, místicos e procura de um sentido para a vida). (Rodrigues; Assmar; Jablonsky, 2009)

Após compreender que a atitude vem antes de comportamento, e que as atitudes não são iguais ao pensamento, é possível entender a diferença entre preconceito e discriminação. As causas do preconceito são variadas, mas pode-se destacar: (1) competição e conflitos econômicos; (2) o papel do indivíduo em que recai todas as culpas (popularmente conhecido como bode expiatório) diante da diminuição do poder de compra, gerando um sentimento de frustração. As oscilações econômicas fazem com que o grupo maioritário culpabiliza o minoritário; (3) fatores de personalidade; (4) causas sociais de preconceito: conformidade com um grupo a qual pertença, determinantes sociais, processos de aprendizagem grupal de repetição do preconceito. (Rodrigues; Assmar; Jablonsky, 2009)

Toda atitude hostil ou negativa com relação a um determinado grupo ou alvo não leva necessariamente à demonstração do preconceito. Conforme Rodrigues; Assmar e Jablonsky (2009), para a Psicologia Social o preconceito é considerado uma atitude, enquanto a base cognitiva é o estereótipo. A pessoa tem uma atitude preconceituosa, e se o ambiente permitir, ela terá um comportamento discriminatório. Em outras palavras, comportamento é discriminação, e, preconceito é atitude (e este encontrase no nível do pensamento).

\subsection{MAIORIA E MINORIA PSICOLÓGICA}

Kurt Lewin (MAILHIOT, 2013) apresenta uma trajetória teórica estudando as minorias judias na Segunda Guerra, e depois expande seus estudos para outros grupos. Por causa disso, ele desenvolveu importantes pesquisas no campo da psicologia de

RC: 105389

Disponível em: https://www.nucleodoconhecimento.com.br/psicologia/processos-grupais 
grupos minoritários versus maioritários, a dinâmica desses grupos. Logo, há uma diferença de minoria e maioria psicológica tanto para a demografia, quanto para a Psicologia. Na demografia está se falando de quantidade de pessoas; então, quando se fala que um grupo é maioria, vai-se ter mais sujeitos no grupo. Entretanto, as diferenças no campo psicológico independem do número de pessoas, pois está ligado ao poder.

Para Lewin (MAILHIOT, 2013), a maioria psicológica possui autonomia (não precisa de outro grupo para existir). Sua existência e futuro não dependem de outros, e justamente por essa maioria psicológica possuir status, poder e autonomia. Sua força se baseia na ciência de definição do futuro coletivo (ou de um sujeito). Ademais, dentro do grupo de maioria psicológica existe uma minoria privilegiada. Este grupo reserva para si privilégios exclusivos que determina o que é adequado ou não.

Já a minoria psicológica está sob tutela, independentemente da quantidade de pessoas. Esses sujeitos se percebem desfrutando de menos direitos, e precisam lutar para alcançá-los. É um grupo que não tem autonomia e é tolerado pelo grupo de maioria psicológica. Portanto, toda minoria psicológica tende a ser discriminada. Se não foi discriminada, é suscetível a ser (MAILHIOT, 2013). Antissemitismo, racismo e sexismo são problemas sociais oriundos dos grupos de maioria psicológica, e para que isso ocorra, desumanizam os grupos de minoria psicológica através do processo de diminuição e jugo. Exatamente por isso, quando o grupo de minoria psicológica começa a se destacar, é perseguido.

Lewin (MAILHIOT, 2013) vislumbra que o problema da minoria psicológica é algo social, não é individual. Quanto mais cedo uma criança oriunda da minoria psicológica souber e compreender sua origem, maiores condições ela terá de identificar situações de discriminação (e até perigo) sem auto culpabilidade; sem tomar para si o ato de descriminalização (TEIXEIRA; ABREU, 2021). É importante que ela tenha consciência de que poderá sofrer discriminação pelo simples fato de fazer parte de um grupo de

RC: 105389

Disponível em: https://www.nucleodoconhecimento.com.br/psicologia/processos-grupais 
minoria, e não por algo que ela faça (ou não). Isso porque o grupo de maioria tende a eleger um bode expiatório, ou seja, alguém para culpabilizar e assim canalizar seus sentimentos de frustração e irritabilidade, e esse alvo encontra-se nos grupos de minoria, não de maioria.

Entender esse processo é importante, pois leva ao terceiro estudo de Lewin (MAILHIOT, 2013) sobre o auto ódio, ou seja, o ódio do próprio grupo (e de si). No caso, o ódio de si cria uma desvalorização do próprio grupo. Essas pessoas não querem ser discriminadas, mas elas vivem em relações intergrupais discriminatórias. É o movimento do oprimido tentando ser aceito pelo opressor, para se tornar igual opressor e/ou acreditando que estará seguro caso consinta com as ações daqueles de maioria psicológica. (TEIXEIRA; ABREU, 2021)

Assim, o ódio de si e do próprio grupo não é porque eles tenham problemas psicológicos, mas porque não querem fazer parte do grupo discriminado. Eles estabelecem o desejo de participar e integralizar o grupo privilegiado. Portanto, o desenvolvimento do ódio pelo próprio grupo que pertence, ocorre pela certeza de seu futuro ser instável e sem status. Logo, segundo Lewin (MAILHIOT, 2013), os grupos são subdivididos por camadas. Pessoas mais ao centro são mais positivas e chamadas de centrípetas, valorizando tradições e cultura de seu grupo. Quem está na extremidade dessas camadas, está sofrendo uma força centrífuga, e, portanto, negativa.

Por fim nesse entendimento sobre maioria e minorias psicológicas, Lewin (MAILHIOT, 2013) percebia que essas coletividades culminariam em uma das três possibilidades:

- Assimilação: quando os grupos de minoria psicológica querem se dissolver no grupo de maioria psicológica. Não querem diferenciação para serem absorvidos pelo grupo de maioria.

RC: 105389

Disponível em: https://www.nucleodoconhecimento.com.br/psicologia/processos-grupais 
- Integração: procuram associações para se aproximar através de semelhanças maiorias e minorias, mas, o problema é que traços da minoria são apagados.

- Independência: seria o único benéfico, pois o indivíduo não diferencia os grupos.

Desta forma, para Lewin (MAILHIOT, 2013), o grupo de minoria psicológica só sobrevive na independência, isto pois, na assimilação ele descaracteriza sua cultura em detrimento da cultura da maioria. Por outro lado, na integração há uma tendência à apropriação cultural, ou seja, da maioria psicológica apropriar-se da cultura da minoria para si. Portanto, somente a independência e autorreconhecimento (de si e do grupo) garantiria a sobrevivência dos grupos minoritários.

\subsection{ENTENDENDO BREVEMENTE OS PROCESSOS GRUPAIS}

Ao se pensar na questão de processos grupais, uma série de autores configuram suas próprias definições, portanto, para cada um deles a função de grupo pode variar. Dos quatro estudiosos que embasam este artigo, pode-se citar rapidamente Lewin (MAILHIOT, 2013), que percebeu um sistema de forças na constituição dos grupos, e, que por fim, teria a função de definição de papéis. Já Pichon-Rivière (BARRETO, 2014) entende a formação de um grupo como um conjunto de indivíduos conectados no tempo e espaço, com algum tipo de vínculo, interagindo por meio de papéis. Além desses autores, pode-se mencionar também Calderón e De Govia (que serão referenciados mais adiante através de LANE, 1989), e até Martin-Baró (apud VIEIRA e XIMENES, 2008).

Quando se fala em processos grupais, e diante dos estudos de Psicologia, torna-se impossível não citar o nome de Sílvia Lane (1989; MARTINS, 2007). A autora debruçase em duas premissas para discutir os processos grupais. Na primeira premissa, entende-se que grupos diferentes podem ter pontos em comum, mesmo havendo

RC: 105389

Disponível em: https://www.nucleodoconhecimento.com.br/psicologia/processos-grupais 
diferenças em seus processos históricos, nas determinações econômicas e nas determinações pessoais. Tudo isso recai sobre a existência e ação de cada grupo.

A segunda premissa que a autora pondera, é que o próprio grupo só pode ser entendido como processo histórico, porque ele muda. Se a identidade do sujeito muda, a identidade do grupo também. Assim, ao invés de se referir a grupo, pode-se referir a um processo grupal, pois, esse grupo ao longo de seu processo histórico vai sendo transformado pelas ações dos indivíduos, pelas pressões (e determinações) econômicas e culturais, e assim por diante. O indivíduo tem sua identidade modificada e igualmente altera a dos outros, precipitando um terceiro movimento, que é a identidade dos outros refletindo no sujeito. (LANE, 1989; MARTINS, 2007; TEIXEIRA; ABREU, 2021)

As crises na identificação de grupo trazem a redefinição do próprio grupo. Calderon e De Govia (apud LANE, 1989, p. 80) definem um grupo como "uma relação significativa entre duas ou mais pessoas", cujas ações são desencadeadas para o alcance de objetivos. Os autores discorrem sobre o processo grupal em estágios, e que esse processo grupal pode ser alterado conforme as crises, sejam elas de diversas dimensões. Portanto, tem-se uma relação significativa entre duas ou mais pessoas, em ações desencadeadoras para a concepção dos objetivos. Entretanto, o que ocorre na constituição dos grupos (pensando em funcionamento como dinâmica de grupo), é que os objetivos individuais são distintos dos objetivos de grupo e a negociação dos objetivos individuais, instala-se aí um conflito. O fato é que os indivíduos geralmente não estão dispostos a negociar com o outro, muito menos para a melhora do objetivo grupal.

Lane (1989) afirma que os indivíduos têm alguns estágios no grupo, e classifica os grupos em quatro tipos: grupo aglutinado (existe a presença de um líder que propõe ações tácitas distribuindo funções dos membros do grupo que ficam esperando soluções); o grupo possessivo (o líder distribui e coordena funções, exigindo a

RC: 105389

Disponível em: https://www.nucleodoconhecimento.com.br/psicologia/processos-grupais 
participação de todos); o grupo coercivo (apresenta um líder coordenador de função, e os membros executam as tarefas com independência, apoio e confiança mútua, contudo, geralmente se fecham para outros de fora); o grupo independente (a liderança é amplamente distribuída entre os membros, e todos indivíduos já possuem autonomia e respondem pelo grupo, e, acolhe novos membros).

Lane (1989) coloca que todo e qualquer grupo exerce uma função histórica, e essa função pode ser para manter ou transformar as relações sociais desenvolvidas em decorrência das relações de produção. Da mesma forma, a autora reforça que a Psicologia Social considera que o sujeito não nasce social, mas torna-se um membro da sociedade, e a socialização primária é este processo de tornar o indivíduo membro da sociedade.

Pelo processo de socialização primária, o sujeito internaliza uma realidade que é tomada pela criança como verdade (não é uma possibilidade; é um mundo real). Por isso, a autora sugere que o psicólogo sócio-histórico ao fazer uma análise de grupos, não fique somente com a análise a nível subjetivo, mas também a nível objetivo. $A$ nível subjetivo (ou seja, da vivência individual), todos se acham livres; todos acreditam que fazem escolhas por si mesmos; todos acham que entendem a vida de uma maneira muito própria. A nível objetivo, as ações e escolhas desse sujeito implicam em como ele se relaciona com os outros, o que nem sempre é condizente com o aspecto subjetivo. Nas relações de grupo, as pessoas apresentam discursos a nível subjetivo que não necessariamente corresponde a ação objetiva que elas têm. (LANE, 1989)

Os autores em que a estudiosa se fundamenta, consideram o grupo como uma relação significativa entre duas ou mais pessoas que se processa por ações desencadeadas para o alcance de objetivos comuns. Outra coisa que ela destaca, são as mediações ideológicas que recaem sobre a ação dos membros do grupo.

RC: 105389

Disponível em: https://www.nucleodoconhecimento.com.br/psicologia/processos-grupais 
Lane (1989) diz que para se entender uma pessoa dentro de um grupo, é necessário analisar tanto sua autorrepresentação (como ela conta sobre si dentro do grupo), quanto reconhecer a realidade objetiva que vai comprimindo e pressionando a ação das pessoas a partir dos papéis sociais e pressupostos daquilo que se espera de como o outro aja. Esse processo grupal leva alguns indivíduos a nem conseguirem dialogar entre si, e para tanto, o psicólogo analisa os sujeitos envolvidos considerando esses dois níveis, o subjetivo e aquele de realidade objetiva. Também é importante no nível objetivo que se reproduza a relação dominador versus dominado, pois é no nível objetivo que podem emergir os processos de oposição, negação e/ou contradição.

Outro ponto importante é a história de vida de cada membro do grupo. Isso tem importância fundamental dentro da análise do processo de grupo. Lane (1989, p. 85) é enfática ao afirmar que "A história de vida de cada um presentifica-se pelas formas concretas através das quais a pessoa age, se coloca, se posiciona, se aliena, se perde ou se recupera ao longo do processo". A autora diz que os psicólogos devem avaliar o nível da ação e da interação grupal, pois é no nível do comportamento que as pessoas colocam as relações de dominação, que expressam a humilhação social de outro, e, portanto, deve atentar-se na ação das pessoas.

Por último, Lane (1989) fala que se deve analisar os papéis sociais, como por exemplo, o papel de líder, já que essa conduta necessita fluir entre os membros do grupo, e não pode ficar estática num único indivíduo. Assim, a autora percebe que a análise do processo grupal não deve ficar na aparência e superficialidade de como os membros apresentam-se, para não perder a dinâmica desse processo grupal.

Lane (1989) e Martin-Baró (apud VIEIRA e XIMENES, 2008) ponderam sobre a concepção de grupo em termos históricos e dialéticos, considerando os aspectos pessoais. Baró também define um grupo como uma estrutura de vínculos e relações humanas que desembocam nas necessidades individuais ou coletivas. Logo, o termo conscientização usado por Martin-Baró e sua visão muito específica sobre o papel do

RC: 105389

Disponível em: https://www.nucleodoconhecimento.com.br/psicologia/processos-grupais 
psicólogo na libertação do indivíduo sobre os aspectos de opressão na América Latina, são oriundos de Paulo Freire (2011), e que precipita a compreensão de que ele é um ser social (TEIXEIRA; ABREU, 2021). Ele diz: "[...] processo de transformação pessoal e social que experimentam os oprimidos latino-americanos quando se alfabetizam em dialética com o seu mundo" (MARTIN-BARÓ, 1997, p. 1516; apud VIEIRA e XIMENES, 2008, p. 27).

Portanto, para a proposta sócio histórica de Martin-Baró, o psicólogo seria o instrumento fundamental e condutor para auxiliar esse sujeito a chegar ao autoconhecimento, tomar a condução de suas próprias escolhas, e, assim, mudar não somente à si mesmo, mas seu grupo social: "não consiste numa simples mudança de opinião sobre a realidade, numa mudança da subjetividade individual que deixe intacta a situação objetiva: a conscientização supõe uma mudança das pessoas no processo de mudar suas relações com o meio-ambiente e, sobretudo com os demais". (MARTIN-BARÓ, 1998, p. 147; apud VIEIRA e XIMENES, 2008; p. 27)

Vieira e Ximenes (2008) reforçam que todo esse processo apontado por Baró é dialético e dialógico, pois implica em mudanças nos moradores do local atendido (a dialética) e no psicólogo (o dialógico), já que este último sai de sua área tradicional de conforto para enfrentar outras realidades de vida. Além disso, todo esse mecanismo de desenvolvimento de conscientização só é alcançado mediante diálogo e enfrentamento de que existem outras realidades além daquelas que um indivíduo possa pressupor: "o reflexo psíquico resulta de uma relação, de uma interação real entre um sujeito material vivo, altamente organizado, e a realidade que o cerca" (LEONTIEV, 1978, p. 93; apud VIEIRA e XIMENES, 2008; p. 31). Essa postura apontada por Baró, de certa forma se assemelha com a proposta de Lewin (MAILHIOT, 2013) no contexto da pesquisa-ação.

Martin-Baró (apud MONTERO, 2010; apud VIEIRA e XIMENES, 2008) expõe a construção da consciência psicopolítica propondo sua aplicação nas comunidades e

RC: 105389

Disponível em: https://www.nucleodoconhecimento.com.br/psicologia/processos-grupais 
desenvolvendo grupos conscientes e fortificados, sendo efetivamente dois aspectos que andam paralelamente em indivíduos e grupos que alcançam o autoconhecimento, e sobre seu entorno. Isso precipitaria sociedades evoluídas e proativas, com sujeitos que abandonam ações e pensamentos egoístas, e o entendimento de grupo alcança a noção de pertencimento e dispara o enfrentamento de problemas. (TEIXEIRA; ABREU, 2021)

Por fim, nessa troca através das várias possibilidades de dinâmicas de grupos (e que quatro delas serão analisadas a partir daqui), todos são beneficiados, pois existe um aprendizado diferenciado, bilateral, em que todos se desenvolvem.

\section{KURT LEWIN}

No capítulo "Da pesquisa-ação à dinâmica de grupos" da obra de Mailhiot (2013), ele explana que Lewin não acreditava na recriação de fenômenos psicológicos em laboratórios, como por exemplo, recriar um ambiente prisional em experimento escolar. Por isso, o entendimento tem que ser comparativo com o fenômeno por uma perspectiva mais globalizada e preferencialmente em campo, e não, limitado ao laboratório.

Sua compreensão de pesquisa-ação (pesquisa e intervenção) era embasado no fato de que o pesquisador não pode ser um elemento neutro na observação, necessitando, portanto, interagir, vivenciar, participar da realidade do qual ele vai investigar. Isso seria alcançado pela participação ativa do pesquisador através da pesquisa participante. Logo, Lewin (MAILHIOT, 2013) fixa dois objetivos congruentes para a pesquisa do psicólogo: (1) ele deve fazer um diagnóstico; (2) ele deve descobrir a dinâmica do grupo.

O psicólogo vai atuar como um pequeno grupo testemunha. Ele vai testemunhar a dinâmica do grupo, possibilitando fazer um diagnóstico de dentro, e não de fora. Assim, de acordo com a dinâmica do grupo concebida por Lewin (MAILHIOT, 2013), RC: 105389

Disponível em: https://www.nucleodoconhecimento.com.br/psicologia/processos-grupais 
o profissional vai atuar como átomo social radioativo. $O$ átomo social radioativo só age quando o grupo está disposto, pois, o psicólogo vai participar daquela realidade fazendo o diagnóstico da situação e descobrindo a dinâmica do grupo.

Lewin (MAILHIOT, 2013) partia do princípio de que o raio de alcance de um único profissional não $s$ para trabalhar com todas as pessoas. Ele pensava em treinar indivíduos formados em Psicologia, sendo que esses replicariam e acolheriam quem estivesse próximo em seu micronúcleo. Assim, além de conhecer melhor as pessoas e grupos ao qual ele interage, a ação seria ampla (do micro para o macro).

O psicólogo pode perceber que o grupo está num momento conformista, não deseja mudança. Nesse caso, ele não vai atuar como átomo social radioativo, pois o grupo está numa posição conformista. Então, dependendo da dinâmica do grupo, o átomo social radioativo tem alcance. Por outro lado, em um mesmo grupo pode haver membros conformistas e membros não conformistas. Os conformistas vão frear de forma velada toda e qualquer mudança. Eles tentarão reprimir de forma sutil (trazendo dúvidas e empecilhos), pois não querem perder possíveis privilégios, ou, o lugar que ocupam. Esses conformistas vão tentar modificar o desejo de mudanças daqueles que o querem. Assim, o átomo social radioativo dá início, mas tende a fracassar, ou ser mais fraco, por causa desses sujeitos que trabalham em oposição. Então, segundo Lewin (MAILHIOT, 2013), no átomo social radioativo existem ao todo três dinâmicas: o grupo dos conformistas; o grupo dos conformistas e não conformistas; o grupo dos não conformistas que querem mudanças.

Nesse terceiro grupo, pode até haver membros conformistas, mas como a maioria é de pessoas que querem mudanças, o átomo social radioativo consegue irradiar novas atitudes e novos comportamentos. Diante disso, Lewin (MAILHIOT, 2013) traz quatro hipóteses para a dinâmica de grupos:

RC: 105389

Disponível em: https://www.nucleodoconhecimento.com.br/psicologia/processos-grupais 
1. O grupo é o campo seguro sócio pessoal: se o grupo não dá status à pessoa, ela se sente num ambiente inseguro (e fica ansiosa e insegura).

2. O grupo é o instrumento de satisfação das necessidades pessoais (por pertencimento, amizade, rede de contato para trabalho, aquisição material).

3. O indivíduo pertence ao grupo mesmo sentindo-se rejeitado.

4. A quarta hipótese é de que o grupo faz parte do espaço de vida da pessoa.

É a partir dessas quatro hipóteses que Lewin (MAILHIOT, 2013) constrói sua noção de adaptação social, e que não é negativa. Portanto, segundo esse autor, a adaptação social é positiva, pois o sujeito consegue realizar seus desejos e objetivos sem romper com a funcionalidade do grupo. Assim, esse indivíduo consegue ter um equilíbrio entre desejo individual e a relação social.

\subsection{A PERSPECTIVA GRUPAL DE LEWIN NO CINEMA}

Não cabe aqui refazer a sinopse na íntegra, já que foi feita anteriormente. Entretanto, cabe pontuar algumas questões que foram relevantes ao se comparar com o trabalho de Lewin (MAILHIOT, 2013). Mas antes, faz-se necessário separar os jurados em seus grupos psicológicos mais contundentes, como apresentado no quadro 1. Cabe lembrar, que os doze homens da trama se encontravam em um mesmo status quo devido a função de jurados naquele instante. Todos tinham o poder decisório nas mãos sobre o destino de um determinado sujeito.

Quadro 1: grupos psicológicos dos jurados

\begin{tabular}{|l|l|}
\hline Grupo de maioria psicológica & Grupo de minoria psicológica \\
\hline Jurado 4. Corretor de Wall Street & $\begin{array}{l}\text { Jurado } 1 . \quad \text { Assistente de treinador } \\
\text { (presidente da mesa) }\end{array}$ \\
\hline $\begin{array}{l}\text { Jurado 10. Empresário de transportes } \\
\text { que estava resfriado }\end{array}$ & \begin{tabular}{l} 
Jurado 2. Bancário \\
\hline
\end{tabular} \\
\hline
\end{tabular}

RC: 105389

Disponível em: https://www.nucleodoconhecimento.com.br/psicologia/processos-grupais 
Jurado 12. Jovem publicitário vaidoso Jurado 3. Empresário de recados com problemas com o filho

Jurado 5 . Homem de origem humilde, mas que ascendeu socialmente

Jurado 6. Trabalhador braçal/pintor

Jurado 7. Apostador de jogos

Jurado 9. Idoso

Jurado 11. Joalheiro de origem europeia

Fonte: Os autores (2021)

O Jurado 8 (representado pelo arquiteto discordante da sentença de culpado) não será colocado nessa lista, já que ele foi o peso decisório para a mudança opinativa dos outros jurados. $O$ jurado 3 está sendo colocado na lista de minoria psicológica, por ser apenas um pequeno empresário. Ele é um trabalhador que ascendeu ao poder, mas não é verdadeiramente poderoso monetariamente, apesar de usar da força e poder para decidir a vida de outros de forma até displicente. Mas, esse personagem será mais discutido adiante.

O debate pela mudança dos votos para inocentar o réu é tenso e muitas vezes tumultuado, mas o jurado 8 tenta provocar a dúvida todo o tempo, e este era o ponto: como condenar sem ter certeza?

Os doze homens que não se conheciam anteriormente, começam a perceber-se mutuamente e onde estariam localizados socialmente, mesmo naquele ambiente de aparente igualdade. É nesse cenário que os fatores de divisão de grupos de maioria e minoria psicológica começam a emergir, e junto com os posicionamentos carregados de preconceitos e discriminações. Assim, após vários contra-argumentos do jurado 8, ele pede uma votação secreta e diz que se um dos onze homens votasse o réu como inocente, eles continuariam a discutir a mudança de votos. Se os onze

RC: 105389

Disponível em: https://www.nucleodoconhecimento.com.br/psicologia/processos-grupais 
votassem como culpado, ele mudaria seu voto igualmente para culpado (já que os doze deveriam votar por unanimidade). Feito isso, e com o surgimento de um segundo voto de inocente, aos 33:15 minutos do filme o jurado 5 é acusado por ter defendido aquele tipo de gente de onde ele veio. Na verdade, o voto de Minerva foi do jurado 9.

Esse jurado 5 teve uma função muito importante, já que ele era o único de origem latina pobre, mas segundo ele mesmo, após sua ascensão, ele tentava esquecer seu passado. Isto é análogo ao terceiro estudo de Lewin (MAILHIOT, 2013) sobre o auto ódio e desvalorização do próprio grupo. Saber que poderia ser discriminado, e, o desejo de participar e integralizar o grupo privilegiado, o colocou em negação de si. Em um determinado momento, e diante de ver que um dos seus, verdadeiramente igual a ele, poderia estar sendo oprimido indevidamente, e em paralelo, ele mesmo estar sendo atacado naquele ambiente (apesar de sua ascensão), sua postura mudou. Não só mudou, mas ele auxiliou com conhecimento de base uma verdade, derrubando uma percepção equivocada.

Aos 56:12 minutos, o jurado 8 recria a ação pelo ponto de vista de uma das testemunhas (um homem idoso e manco), com a ajuda dos outros jurados. Com $1 \mathrm{~h}$ e 14 minutos de filme, ele igualmente recria o momento do esfaqueamento (que segundo o laudo, foi feito de cima para baixo, sendo a vítima cerca de 25 centímetros mais alta que o réu). A simulação começa com o jurado 3 , mostrando com fúria que 0 réu foi culpado, mesmo sendo menor. $O$ jurado 5 intervém e revive sua experiência pessoal, saindo das sombras de sua própria historicidade, mostrando que uma faca daquelas (de mola) jamais seria manipulada de cima para baixo, mas de baixo para cima imediatamente após seu acionamento, e ainda mais por alguém com experiência com facas como os jovens locais (e que era especificamente o caso do réu).

Todo esse processo de recriação se encaixa com a teoria da pesquisa-ação de Lewin (MAILHIOT, 2013). O jurado 8, apesar da raiva de muitos jurados (e notoriamente aqueles irredutíveis da maioria psicológica e mais o jurado 3), utilizou-se desse

RC: 105389

Disponível em: https://www.nucleodoconhecimento.com.br/psicologia/processos-grupais 
descontentamento levando-os a participar das ações. Ele alcançou o propósito de ser o átomo social radioativo daquele espaço, mesmo com a relutância de alguns, mas, aos poucos, levando outros à reflexão.

Com 1 h e 18 minutos do filme, o preconceito e discriminação do jurado 10 se manifestou, gerando o comportamento unificado de reprovação de todos os outros sujeitos. Quando percebeu que nenhum membro do grupo Ihe deu voz, recolheu-se desacreditado, e isso deu espaço para um dos discursos mais importantes da trama pelo jurado 8:

É sempre difícil manter um preconceito pessoal fora de uma questão como esta. Sempre que se defronta com eles, ele esconderá a verdade. Sinceramente eu não sei qual é a verdade, e, também, acho que realmente nenhum de nós saberá. Nove de nós parecem achar que esse garoto é inocente, mas só estamos lidando com probabilidades. Podemos estar errados; podemos estar deixando um homem culpado ficar livre, eu não sei, e acho que ninguém sabe. Mas nós temos uma dúvida racional, e isto é uma coisa muito valiosa no nosso sistema. Nenhum júri pode declarar um homem culpado se não tiver certeza absoluta. Nós, os nove, não podemos entender como vocês três têm tanta certeza. (LUMET, 1957, 1:20:35)

O comportamento discriminatório do jurado 10 diante dos fatores de impacto nas relações sociais corrobora com os estudos de Rodrigues, Assmar e Jablonsky (2009). Foi interessante observar que outros no grupo que consentiam anteriormente com seu posicionamento no início do filme, naquela altura, e com o grupo já mudando seu pensamento preconceituoso ao se depararem com o entendimento que suas verdades estavam distorcidas, passaram a comportar-se em contrariedade com o jurado 10, mesmo os dois que ainda defendiam a condenação do réu.

O jurado 4 foi igualmente convencido pelo jurado 9 a mudar seu voto para inocente, após ser confrontado com sua própria experiência como usuário de óculos e com deficiência visual. O idoso (que desde o início apoiou o jurado 8) seguiu o exemplo de ação como átomo social radioativo, levando o reticente corretor à reflexão a partir de si mesmo.

RC: 105389

Disponível em: https://www.nucleodoconhecimento.com.br/psicologia/processos-grupais 
A dinâmica de grupo e a condução de reflexão estavam afetando profundamente cada homem ali, até porque, o jurado 8 insistia em provocar os poucos resistentes, até restar somente um, o jurado 3 :

Jurado 8: Queremos ouvir seus argumentos. Jurado 3: Eu já listei meus argumentos! Jurado 8: Não estamos convencidos. Queremos ouvir de novo. (LUMET, 1957, 1:29:53)

O enraivecido jurado 3 , que tentava condenar a todo custo o réu de 18 anos, confirmou ao tempo de $1 \mathrm{~h}$ e 32 minutos do filme, que toda sua fúria era apenas uma projeção de sua relação com o próprio filho. O contraste do silêncio sepulcral e olhares do grupo com o acesso de raiva do homem rasgando a foto do filho, acabou the mostrando que a condenação do réu era como se ele estivesse condenando o próprio filho. Era uma vingança diante de sua própria frustração como pai.

Nenhum dos autoenfrentamentos seriam possíveis sem o choque entre os sujeitos no grupo, sem o embate e provocação conduzida pelo jurado 8 para a comparação consigo mesmos, sem a recriação das ações do contexto do julgamento, mas, sobretudo, se não houvesse a participação ativa de pessoas com vivências reais que estavam presentes e podiam fazer a diferença com seus próprios históricos.

\section{JACOB MORENO}

O embrião do Psicodrama terapêutico de Jacob Levy Moreno (BARRETO, 2014) foi formado no Teatro da Espontaneidade em 1922. Por meio de encenações, o paciente, grupo, ou protagonista, podem reviver sua criatividade e espontaneidade com atenção na resolução de problemas. O que fez Moreno perceber a potência das encenações nos trabalhos em grupo foi o caso Bárbara-George, quando uma atriz conseguiu dar vazão aos seus impulsos agressivos ao utilizar a criatividade (BARRETO, 2014). De acordo com Liliana Lima (2014, p. 55-83), o homem para Moreno é relacional e foi por meio dessas relações que ele estruturou sua teoria.

RC: 105389

Disponível em: https://www.nucleodoconhecimento.com.br/psicologia/processos-grupais 


\subsection{A PERSPECTIVA GRUPAL DE MORENO NO CINEMA}

Durante as cenas do filme "Doze homens e uma sentença" (LUMET, 1957), pode-se observar duas das grandes teorias de Moreno (BARRETO, 2014): o psicodrama e o sociodrama. Apesar de ambas serem muito próximas, são linhas diferentes. $O$ psicodrama seria a dramatização do psiquismo; é uma terapia de grupo na qual se trabalha com o paciente e participantes que vão discutindo questões inerentes a sua própria vida. É comum utilizar uma determinada questão do indivíduo e vivenciar no grupo:

Psicodrama é a ciência que explora a verdade por meio de métodos dramáticos, e que lida com relações interpessoais e com mundos privados. Vale-se de cinco instrumentos: o palco, sujeito ou ator, diretor, equipe de ajudantes terapêuticos ou egos auxiliares e o público (sendo que cada instrumento tem uma função específica). (RUSSO, 2010, p. 180)

Segundo Russo (2010), o sociodrama é uma teoria de grupo que não se limita a um número especial de indivíduos, podendo consistir em todas as pessoas que vivem em um determinado lugar e em determinada época. Portanto, considerando uma questão social de forma mais ampla que o psicodrama, e levando em conta o momento da época na qual está sendo debatida a questão, pode-se observar esses dois elementos da teoria de Moreno (BARRETO, 2014) durante o longa de Lumet (1958). Isto é visto em um primeiro momento, quando estão debatendo o tema central do julgamento de culpabilidade ou não. Em uma segunda parte, porque isso está relacionado a sobrevivência do réu, ou seja, a vida do outro pertence ao julgamento do grupo (uma vez que proferida a sentença de culpado, a condenação será a pena de morte). Em um terceiro momento, o ambiente na qual está instaurada a sessão e quais são os fatores do contexto que exige desse julgamento. Russo (2010, p. 181) diz: "O homem é um desempenhador de papéis, cada indivíduo é caracterizado por um conjunto de papéis que preside seu comportamento, e cada cultura caracteriza-se por um determinado conjunto de papéis imposto por ela a seus membros."

RC: 105389

Disponível em: https://www.nucleodoconhecimento.com.br/psicologia/processos-grupais 
Já nos aspectos do psicodrama, no qual terá como ponto principal a problematização individual e subjetiva, observa-se que cada um traz um pouco de suas questões pessoais como problemas familiares e sentimentos como por exemplo, a saudade. Dessa forma, a sessão de julgamento permite que as afetividades se cruzem, ainda que de maneira involuntária e explicada por Russo (2010, p. 178): “(...) de modo geral, o mesmo princípio aplica-se a qualquer situação em que uma pessoa tem um tipo de personalidade que requer determinados tipos de pessoas, por meio das quais suas emoções poderiam encontrar uma forma adequada de expressão."

Para Nery e Conceição (2005), a importância da teoria de Moreno (BARRETO, 2014) nos processos grupais é a possibilidade de compreensão por meio da ação e comunicação dos indivíduos participantes do grupo. Por meio desse entendimento, surgem resoluções de conflitos que estavam cristalizados graças a criatividade e espontaneidade que gera uma catarse. Em paralelo, Lima (2014) explica que ao buscar fundamentar sua teoria, Moreno criou o conceito de sociometria, depois incluído em uma conceituação chamada socionomia, que visava mensurar e investigar as relações interpessoais. A partir de então, sua teoria foi reformulada e outros profissionais a incorporaram em práticas terapêuticas e as aperfeiçoaram.

No filme, o grupo começou a se preparar para a ação quando todos estavam presentes na sala. A sala pode ser lida como o cenário, que na teoria de Moreno (BARRETO, 2014), é onde ocorre a ação dramática e é um dos cinco instrumentos da técnica. Nesse momento, eles são obrigados a interagir para resolver um conflito judicial mesmo que alguns não desejam participar inicialmente do processo.

Para Lima (2014), o aquecimento é uma das etapas do Psicodrama onde o grupo se prepara para a ação e é delineado o protagonista. Para isso, surge em cena o relator do caso, o jurado número 1, que pode ser explicado como o diretor da cena que, segundo essa autora, é responsável por garantir ordem, ser o terapeuta do grupo e do protagonista. No filme, esse personagem começa indicando os locais de cada um

RC: 105389

Disponível em: https://www.nucleodoconhecimento.com.br/psicologia/processos-grupais 
na sala, pedindo a todos a colaboração e indicando que a sentença do grupo é essencial para a execução ou não da pena do acusado. Mesmo com a discordância de alguns em discutir o caso extensivamente, todos concordam em manter seus lugares na sala.

É nesse momento que surge o protagonista do grupo. Conforme Lima (2014, p. 69), a importância desse personagem é a de representar as emoções do grupo, trazer questionamento para a ação e assim sintetizar o projeto dramático em comum. $\mathrm{O}$ jurado 8, visto como o protagonista emergente, é o único que se recusa a seguir com a mentalidade da maioria, mesmo com a reclamação de alguns. Nesse ponto, a autora explica que ocorre o aquecimento específico do protagonista onde ele começa a se preparar para a ação dramática em si. Até esse ponto, todos estavam tentando se conhecer, foi somente quando o protagonista se preparou para começar a agir, que surgiram as dramatizações do conflito.

O jurado 8 inicia sua ação elencando os motivos pelos quais ele acredita que o réu não é culpado, mas, também pode não ser inocente, dando assim o benefício da dúvida para o jovem acusado. Após sua fala, na qual todos se inquietam, o jurado 1 indica que o melhor a se fazer, é todos se colocarem no caso, indicando os motivos pelos quais tiveram aquela decisão. Para a teoria moreniana na dramatização, e com base na fala de cada um, o grupo poderia então buscar uma resolução do problema de divergência ao convencer o jurado 8 de que a decisão da maioria é a melhor. Lima (2014) aponta que o compartilhamento ocorreria no instante em que o grupo participa da ação na cena, quando cada um expõe seus sentimentos e ideias por meio do diálogo. É importante para os outros integrantes do grupo participarem, e, assim, terse uma melhor visão do questionamento como um todo.

Um por um inicia sua teoria, dando palpites sobre o que poderia ter ocorrido no momento do crime, e para mostrar ao jurado 8 que sua ideia estava equivocada. Porém, o jurado 8 não renuncia a sua decisão. Percebe-se que o protagonista é

RC: 105389

Disponível em: https://www.nucleodoconhecimento.com.br/psicologia/processos-grupais 
dotado de espontaneidade, segundo a teoria de Moreno (BARRETO, 2014). Nery e Conceição (2005) explicam que a espontaneidade equivale a dar respostas novas para um problema, funcionando como um elemento constitucional do homem, e sendo por meio dela que surge toda produção criativa. Logo, o jurado 8 rebate as críticas feitas pelos seus colegas com muita criatividade, utilizando até mesmo elementos de cena para suas explicações. Ademais, mesmo quando confrontado fisicamente, por meio de brigas mais acaloradas, ele busca sair da situação de conflito mostrando um outro lado da situação-problema. Portanto, apesar de no começo ainda ter dúvidas sobre o processo, busca em si, por meio criativo, as respostas.

Lima (2014) explica que a espontaneidade favorece o bom desenvolvimento humano, porém fatores ambientais e sociais fazem com que essa característica seja prejudicada na medida que o sujeito se desenvolve na sociedade. Com isso, a criatividade torna-se cristalizada (como se fosse congelada) pela conservação social. Moreno (BARRETO, 2014) chama esse fenômeno de Conserva Cultural, na qual o homem não tem mais uma criatividade e espontaneidade que surge naturalmente em momentos problemáticos. O jurado 3 seria um exemplo de personagem tomado pela conserva cultural. Com valores sociais severos, buscou criar seu filho da mesma forma e foi abandonado por ele devido às suas constantes punições. Seu ato criativo ficou cristalizado e ele somente repete o que escutou na sua criação conservadora. Um dos exemplos seria quando ele indica: "Não se criam mais filhos como antigamente" (LUMET, 1958). Com essa fala ele quer dizer que é melhor continuar a mesma forma de educação rígida na qual foi criado, pois assim seria perpetuada a cristalização da instrução social. Visto como o antagonista, aquele que busca um embate constante com o protagonista, o jurado 3 não renuncia a sua posição cristalizada, mesmo com o surgimento de novas ideias, demonstrando que está tomado pela conservação cultural.

Por fim, Lima (2014) afirma que seria por meio da prática psicodramática que a espontaneidade poderia surgir novamente, visando recuperar o homem sensível, RC: 105389

Disponível em: https://www.nucleodoconhecimento.com.br/psicologia/processos-grupais 
genial e criativo. E é isso que o protagonista tenta fazer aos poucos com os jurados que acreditavam que o réu era culpado. Por meio de práticas como dramatizações, instrumentos de cena e diálogo, ele tenta resgatar a criatividade e sensibilidade de cada um. O importante não é o jurado 8 influenciar os outros a mudarem de ideia, mas sim, fazer com cada um repense a sua escolha e pondere com sua própria criatividade.

\section{WILLIAM C. SCHUTZ}

Pode-se identificar na obra de Schutz (1979), "O Prazer - expansão da consciência humana", que nas relações interpessoais há três necessidades básicas interpessoais existentes em todos os grupos e que precisam ser satisfeitas para que ocorra a evolução do relacionamento intergrupal. As áreas de necessidades interpessoais foram denominadas de inclusão, controle e afeição/abertura, ocorrem nesta ordem no desenvolvimento dos grupos, as quais serão apresentadas resumidamente a seguir.

O comportamento de inclusão diz respeito à associação entre indivíduos, a fazer parte, estarem rodeados de pessoas. Segundo o autor, esta necessidade de ser incluído, evidencia-se "como o desejo de merecer consideração e de atrair atenção e interesse" (SCHUTZ, 1979, p. 101). A inclusão caracteriza-se pela procura de interação com outros indivíduos, desejo de atenção, reconhecimento, prestígio e interação com a própria individualidade. No decorrer do processo de formação de grupo, o estudioso diz que a principal preocupação do indivíduo é transgredir ou não os limites do grupo, e de pertencer ou não a ele.

O comportamento controlador tem relação com o processo de decisão entre pessoas, áreas de poder, influência e poder. Essa necessidade de poder pode variar desde o desejo de poder e controle sobre os outros, até a necessidade de ser controlado e ser isento de responsabilidades. Esse comportamento também se manifesta em pessoas que tentam controlar - a manifestação de independência e de revolta é um exemplo

RC: 105389

Disponível em: https://www.nucleodoconhecimento.com.br/psicologia/processos-grupais 
de falta de propensão a ser controlado, a submissão e o cumprimento de ordens indicam os graus variáveis de aceitação de controle. (SCHUTZ, 1979; 1989)

O comportamento de afeição, diz respeito aos íntimos sentimentos emocionais entre dois indivíduos, e, de acordo com Schutz (1979), é uma relação dual, que só acontece entre pares, diferente das relações inclusivas que ocorrem entre pares, ou uma pessoa e outro grupo de pessoas. Em grupos, segundo Schutz (1979, p. 103), "o comportamento afetivo caracteriza-se por demonstrações de amizade e diferenciação entre membros", e, inclui a luta pela liderança e competição. Esse comportamento, está relacionado ao quanto que o indivíduo está disposto a ser aberto com o outro, podendo variar ao longo do tempo, entre pessoas e nos relacionamentos. Assim, é construída com base em vínculos mais profundos, por isso, geralmente é a última fase a emergir em um relacionamento entre as pessoas ou em um grupo. (SCHUTZ, 1979; 1989).

\subsection{A PERSPECTIVA GRUPAL DE SCHUTZ NO CINEMA}

O filme "Doze homens e uma sentença" (LUMET, 1957) apresenta os fatores envolvidos no processo grupal em um momento que será decisivo, evidenciando como os indivíduos levam para o grupo e para a tomada de decisões, suas experiências de vida e seus padrões de condicionamento histórico. Evidenciando as dissemelhanças individuais dos sujeitos, levando à análise do mesmo fato por perspectivas diferentes.

Como já relatado em outros trechos deste artigo, após a pausa do julgamento, os doze homens que pertencem ao júri são levados para uma sala reservada no tribunal para que discutam o caso e decidam sobre a sentença do jovem acusado. Nesse momento, inicia-se a fase denominada por Schutz (1989) de inclusão. É possível identificar o início do processo na formação do grupo responsável pela sentença. Os jurados se apresentam entre si, tomam seus assentos e começam a conversar a fim de organizarem-se na mesa.

RC: 105389

Disponível em: https://www.nucleodoconhecimento.com.br/psicologia/processos-grupais 
Na dimensão de inclusão, Schutz (1989) apresenta que o comportamento é definido pela maneira como o indivíduo sente a respeito do que significa como pessoa. Então, ele torna-se uma pessoa sub social, ultra social ou social. Importante ressaltar que esta fase de inclusão não implica necessariamente que haja fortes conexões emocionais ou de domínio em relação aos demais, mas sim, de um processo na formação grupal.

- Sub social - Indivíduo com esta característica é introvertido e retraído. Opta por manter distância dos outros para não se misturar, pois, se fizesse perderia sua privacidade. Desejam inconscientemente que as pessoas prestem atenção neles, mas seu maior medo é ser ignorado pelas pessoas e que estas não se aproximem, por este motivo as evita.

- Ultra social - Indivíduo com esta característica é extrovertido, busca por companhia e atenção, mas deseja ser procurado por elas. Tem medo de ficar sozinho e de ser ignorado pelas pessoas e que estas não se aproximem, mas seu comportamento manifesto é diferente do Sub social, ele vai atrás das pessoas para estabelecer relações.

- Social - Indivíduo com esta característica não apresenta problemas com interação social. Sente-se bem com ou sem a presença dos outros. Pode participar muito ou pouco do grupo, sem se sentir ansioso. Pode se comprometer e se envolver bastante com o grupo, ou pode simplesmente evitar o grupo (se sentir que é melhor assim). Sente que têm seu próprio valor. (SCHUTZ, 1989)

Para uma melhor compreensão do exposto acima pela perspectiva do autor, foi realizada a divisão dos personagens (quadro 2) de acordo com esses comportamentos observados.

RC: 105389

Disponível em: https://www.nucleodoconhecimento.com.br/psicologia/processos-grupais 
Quadro 2: Características sociais dos indivíduos do grupo de jurados.

\begin{tabular}{|c|c|c|}
\hline Sub social & Ultra Social & Social \\
\hline $\begin{array}{l}\text { Jurado 2. Bancário. } \\
\text { Jurado } 5 \text {. Homem de } \\
\text { origem humilde. } \\
\text { Jurado } 6 \text {. Trabalhador } \\
\text { braçal/Pintor. } \\
\text { Jurado 9. Idoso } \\
\text { Jurado } 11 \text {. Joalheiro } \\
\text { de origem europeia. } \\
\text { Jurado } 12 \text {. Jovem } \\
\text { publicitário vaidoso. }\end{array}$ & $\begin{array}{l}\text { Jurado 3. Empresário de } \\
\text { recados. } \\
\text { Jurado } 7 \text {. Apostador de } \\
\text { jogos. } \\
\text { Jurado 10. Empresário de } \\
\text { transportes que estava } \\
\text { resfriado. }\end{array}$ & $\begin{array}{l}\text { Jurado 1. Assistente de } \\
\text { treinador (presidente da } \\
\text { mesa). } \\
\text { Jurado 4. Corretor de Wall } \\
\text { Street Corretor. } \\
\text { Jurado 8. Arquiteto (homem } \\
\text { discordante da sentença de } \\
\text { culpado). }\end{array}$ \\
\hline
\end{tabular}

Fonte: Os autores (2021)

Para que haja formação de um grupo é necessário que exista uma semelhança em comum a todos (SCHUTZ, 1989); nesse caso, o dever de decidir sobre a pena do réu faz com que os doze jurados formem um grupo. Assim, com 3 minutos de filme é possível identificar o início do processo na formação do grupo responsável pela sentença. Os jurados ajudam o policial a montar a mesa e organizar as cadeiras para que todos possam se acomodar. Seis segundos depois, o jurado 7 oferece chicletes para o jurado 10, e na sequência, o jurado 7 começa a conversar com o jurado 2 sobre o clima quente do dia, buscando interação com os demais integrantes com o intuito de enturmar-se no grupo. Aos 5 minutos e 57 segundos, os jurados tomam seus assentos a fim de estruturar-se no grupo. Após acomodarem-se em volta da mesa, 0 RC: 105389

Disponível em: https://www.nucleodoconhecimento.com.br/psicologia/processos-grupais 
grupo faz a diferenciação de papéis e distribui o poder. Fica instituído que o jurado 1 será o presidente da mesa.

Na dimensão do controle, para Schutz (1989), subjacente ao comportamento de controle está a percepção de competência. O indivíduo sente-se competente, possui capacidade de enfrentar o mundo, satisfazer os seus desejos, manter seu trabalho e adquirir bens materiais. Tornando-se uma pessoa abdicrata, autocrata ou democrata. Importante ressaltar que o problema do controle é estar por cima ou por baixo. A interação primária do controle é o confronto, enquanto a ansiedade/medo do controle é ser incompetente. (SCHUTZ, 1989)

- Abdicrata - Quando o indivíduo abdica do poder, aceitando uma posição subordinada, na qual não há necessidade de assumir responsabilidade pela tomada de quaisquer decisões. Não exerce liderança, não controla os outros (mesmo que isso lhe seja favorável). Nunca toma decisão, prefere encaminhar para o outro tomar por se achar incapaz.

- Autocrata - Refere-se ao indivíduo extremamente dominador, fanático por poder, e competidor. Estes têm receio que os outros não sejam influenciados por ele e pior, que acabem influenciando-o. Não se sente capaz de tomar decisão e por este motivo tenta provar que é capaz e com isso, acaba assumindo uma carga de responsabilidade grande demais.

- Democrata - Este indivíduo sente-se confortável em dar ordens, dependendo do que for mais apropriado para a situação. Sente-se competente e confiante e acredita que as pessoas também confiam em sua capacidade de tomar decisões. (SCHUTZ, 1989)

Para uma melhor compreensão do exposto acima, foi realizada a divisão dos personagens de acordo com os comportamentos observados (quadro 3).

RC: 105389

Disponível em: https://www.nucleodoconhecimento.com.br/psicologia/processos-grupais 
Quadro 3: Características de controle dos indivíduos do grupo de jurados.

\begin{tabular}{|c|c|c|}
\hline Abdicrata & Autocrata & Democrata \\
\hline $\begin{array}{l}\text { Jurado 2. Bancário. } \\
\text { Jurado } 5 \text {. Homem de } \\
\text { origem humilde. } \\
\text { Jurado } 6 \text {. Trabalhador } \\
\text { braçal/Pintor. } \\
\text { Jurado 9. Idoso } \\
\text { Jurado } 11 . \text { Joalheiro } \\
\text { de origem europeia. } \\
\text { Jurado } 12 \text { Jovem } \\
\text { publicitário vaidoso. }\end{array}$ & $\begin{array}{l}\text { Jurado 3. Empresário de } \\
\text { recados. } \\
\text { Jurado } 7 \text {. Apostador de } \\
\text { jogos. } \\
\text { Jurado 10. Empresário de } \\
\text { transportes que estava } \\
\text { resfriado. }\end{array}$ & $\begin{array}{l}\begin{array}{l}\text { Jurado 1. Assistente de } \\
\text { treinador (presidente da } \\
\text { mesa). }\end{array} \\
\text { Jurado 8. Arquiteto (homem } \\
\text { discordante da sentença de } \\
\text { culpado). }\end{array}$ \\
\hline
\end{tabular}

Fonte: Os autores (2021)

Aos 8 minutos e 55 segundos de filme, é possível observar a tentativa de controle que o jurado 3 tenta exercer sobre o jurado 8 (após o jurado 8 ser o único discordante da sentença do réu votada por todos os jurados), afirmando que ele viu que o réu é culpado e perigoso, e não restariam dúvidas sobre isso. O comportamento de controle refere-se ao processo de tomada de decisão entre pessoas na área do poder, da influência e da autoridade. Também pode ser observado em relação às pessoas que tentam controlar (SCHUTZ, 1989). Ou seja, nessa cena há uma disputa por controle/autoridade dos jurados.

RC: 105389

Disponível em: https://www.nucleodoconhecimento.com.br/psicologia/processos-grupais 
No decorrer do filme, é possível observar a tentativa de controle sendo exercida pelos jurados 3,7 e 10, os quais tentam ativamente convencer o jurado 8 a mudar seu posicionamento de voto e consequentemente sentenciar o réu. Por volta dos 14 minutos e 10 segundos de filme, o jurado 8 passa a exercer o poder de controle, na medida em que ele começa a influenciar com a sua percepção os demais jurados, os quais gradativamente ficam em dúvida, e, por fim, a alteraram seu voto a favor da inocência do réu. Durante o estágio de controle, o comportamento grupal inclui a luta pela liderança e pela competição. (SCHUTZ, 1989)

O jurado 8 exerce o poder de liderança sobre os demais membros do grupo, de modo que as pessoas passam a observar seu ponto de vista bem como sua postura e a partir de então, estas são influenciadas. O líder tem a capacidade de influenciar os significados e consequentemente, os valores dos demais. Esse tipo de conduta colabora na superação de conflitos, condição essencial para o bom andamento de uma equipe, visto que a interpretação de situações pode igualmente conduzir os membros para uma compreensão de realidade em comum. (SMIRCICH e MORGAN, 1982).

De acordo com Schutz (1989), a afeição é quanto a pessoa está disposta a ser aberta com o outro, variando ao longo do tempo entre indivíduos e relacionamentos. Logo, há três tipos de indivíduos: o subpessoal, o superpessoal e o pessoal. Importante ressaltar que há necessidade de vínculo afetivo nas relações e é geralmente a última fase a manifestar-se no desenvolvimento de uma relação humana ou de um grupo.

- Subpessoal - O indivíduo subpessoal, evita elos íntimos com outras pessoas, mantêm as relações num nível distante e superficial e sente-se satisfeito quando os outros agem dessa mesma maneira com ele, mantendo uma distância emocional e não se envolvendo emocionalmente. Teme que não seja amado e querido pelos outros e tem dificuldade de gostar de outras pessoas e desconfia dos sentimentos dos outros a seu respeito. A técnica da pessoa

RC: 105389

Disponível em: https://www.nucleodoconhecimento.com.br/psicologia/processos-grupais 
subpessoal é ser superficialmente amigo de todos, evitando que se torne próximo de alguém.

- Superpessoal - O indivíduo superpessoal se torna extremamente próximo dos outros e espera que os outros também se aproximem dele. Então torna-se uma pessoa querida com objetivo de aliviar a ansiedade de ser rejeitado e nãoquerido. Com isso, tenta conquistar a aprovação do outro, ser extremamente pessoal, agradável, íntimo e confiável.

- Pessoal - $O$ indivíduo pessoal, por ser bem resolvido nas suas relações de afeto na infância, a interação com outras pessoas não constitui problemas. Sente-se bem em uma relação íntima e em uma relação que exige distanciamento emocional. É capaz de dar e receber afeto genuíno. (SCHUTZ, 1989)

Para uma melhor compreensão do exposto acima, foi realizada a divisão dos personagens de acordo com os comportamentos observados (quadro 4).

Quadro 4: Características de afeto dos indivíduos do grupo de jurados.

\begin{tabular}{|l|l|l|}
\hline $\begin{array}{l}\text { Subpessoal } \\
\text { Jurado 3. Empresário de } \\
\text { recados. }\end{array}$ & $\begin{array}{l}\text { Jurado 7. Apostador } \\
\text { de jogos. }\end{array}$ & $\begin{array}{l}\text { Jurado 1. Assistente de } \\
\text { treinador (presidente da } \\
\text { mesa). }\end{array}$ \\
$\begin{array}{l}\text { Jurado 4. Corretor de Wall } \\
\text { Street Corretor. }\end{array}$ & $\begin{array}{l}\text { Jurado 12. Jovem } \\
\text { publicitário vaidoso. }\end{array}$ & $\begin{array}{l}\text { Jurado 6. Trabalhador } \\
\text { braçal/Pintor. }\end{array}$ \\
$\begin{array}{l}\text { Jurado 5. Homem de } \\
\text { origem humilde. }\end{array}$ & $\begin{array}{l}\text { Jurado 8. Arquiteto (homem } \\
\text { discordante da sentença de } \\
\text { culpado). }\end{array}$ \\
$\begin{array}{l}\text { Jurado 10. Empresário de } \\
\text { transportes que estava } \\
\text { resfriado. }\end{array}$ & Jurado 9. Idoso \\
\hline
\end{tabular}

RC: 105389

Disponível em: https://www.nucleodoconhecimento.com.br/psicologia/processos-grupais 
Jurado 11. Joalheiro de origem europeia.

Fonte: Os autores (2021)

Alguns membros do grupo sentem-se bem em qualquer situação, seja ela calorosa ou distante. O jurado 8 enfrentou durante todo o processo várias críticas dos demais jurados, por não ser a favor da acusação; no entanto, ele pareceu estar bem em situações que aceitavam os seus argumentos, até mesmo quando eram rejeitados. Conforme mencionado por Schutz (1989), para o indivíduo enquanto pessoa, é importante ser querido; mas, se não for, aceita essa relação, não significando que é alguém incapaz de ser amado.

O jurado 11 é um homem sério e calado, apresentando sua opinião apenas quando eram relevantes ou questionando os demais jurados. Na terceira votação, aos 57 minutos e 38 segundos do filme, quando é indagado pelo jurado 3 sobre a mudança de voto, ele afirma que não deve explicações e que apenas tem uma dúvida razoável. Observa-se durante o filme que o jurado 11 mostrou-se um indivíduo subpessoal, guardando distância dos demais jurados e mantendo as relações superficiais, o que é análogo às explicações de Schutz (1989).

Aos 4 minutos e 40 segundos, o jurado 8 difere-se dos demais ao ficar isolado e olhando pela janela, mostrando-se reflexivo. Então, o jurado 12 aproxima-se e the pergunta o que achou do julgamento, comentando que o achou interessante. Aos 6 minutos e 33 segundos, o jurado 11 pergunta ao jurado 12 "qual foi a sua impressão sobre o promotor", e o jurado 12 responde que "ele foi muito preciso, a maneira como ele explicou todos os pontos, em sequência lógica - os caras são muito espertos" (LUMET, 1957). Em seguida, todos os jurados são chamados pelo relator e se sentam à mesa, é então quando o jurado 12 comenta sobre a atuação impecável do juiz. Após

RC: 105389

Disponível em: https://www.nucleodoconhecimento.com.br/psicologia/processos-grupais 
a primeira votação, em que o jurado 8 acredita que o jovem é inocente, o jurado 12 diz que "talvez seja dever do grupo convencer o senhor que nós é que estamos certos e ele errado - se cada um de nós usar um minuto ou dois para explicar nossa opinião, talvez...", mas ao mesmo tempo retira sua colocação, após alguns olhares de reprovação e comenta "foi só uma ideia" (LUMET, 1957, 00:12:40). Observa-se no jurado 12 características de um indivíduo superpessoal, em que tenta se manter próximo de todos no decorrer do filme. Usando como técnica direta o fator de ser querido, e, assim, tenta conquistar a aprovação dos demais e ser agradável. (SCHUTZ, 1989)

\section{PICHON-RIVIÈRE}

Nascido em 1907, em Genebra, Enrique J. Pichon-Rivière (2009) foi um psiquiatra suíço que trouxe grande contribuição para a compreensão dos grupos. Teve como pilares de seus estudos a psicologia social e a psicanálise, mas gradualmente abandona a psicanálise ortodoxa para se dedicar a um novo enfoque epistemológico que o leva para a Psicologia Social. A partir disso, inaugurou uma forma de intervenção aos grupos, sendo assim considerado por muitos autores, o criador da teoria e técnica dos grupos operativos.

\subsection{A PERSPECTIVA GRUPAL DE PICHON-RIVIÈRE NO CINEMA}

Para Pichon-Rivière (2009), a psicologia social é uma ciência das interações sociais com o objetivo de mudanças sociais de modo planejado:

Se não for assim, não tem sentido, e todos os seus esforços levariam a um sentimento de impotência, como resultante das contradições quanto a seu aspecto operacional. É um artesanato, no sentido mais amplo da palavra, que tanto forma os elementos da mudança como prepara o campo no qual se vai atuar. (PICHON-RIVIĖRE, 2009, p. 169-170)

RC: 105389

Disponível em: https://www.nucleodoconhecimento.com.br/psicologia/processos-grupais 
Nesse sentido, a abordagem pode seguir em duas direções: (1) a psicologia social acadêmica, que se preocupa principalmente com as técnicas e suas problemática ou com as possibilidades de mudança. (2) A práxis, onde, segundo o autor, surge o objetivo central, voltado ao instrumental e operacional de modo mais real, não sendo, portanto, fechada em um círculo, mas em uma contínua realimentação da teoria, através do confronto com a prática e vice-versa. Nesse sentido se estabelece uma marcha espiral, que gradualmente capacita a mente para construir uma estratégia que estrutura a mudança esperada. (PICHON-RIVIÈRE, 2009)

Segundo o autor, a partir dessa visão da práxis, é possível a criação de um instrumento único, aqui denominado como ECRO - Esquema Conceitual, Referencial e Operativo, que é orientado para aprendizagem a partir de uma tarefa.

Esse conjunto estrutural e genético permite-nos a compreensão horizontal (a totalidade comunitária) e vertical (o indivíduo nela inserido) de uma sociedade em permanente situação de mudança e dos problemas de adaptação do indivíduo a seu meio. Como instrumento, é o que permite planejar um manejo das relações com a natureza e seus conteúdos, nas quais o sujeito se modifica a si mesmo e modifica o mundo, num constante interjogo dialético. (PICHONRIVIĖRE, 2009, p. 171)

Assim sendo, o ECRO é instrumental e operacional, pois é aplicável a qualquer setor de investigação e tarefa, sendo muito importante no grupo operativo. Um grupo operativo nada mais é do que um grupo centrado, de forma explícita, em uma tarefa. Nesse sentido, é todo o conjunto de pessoas, que estão ligadas por constantes de espaço e tempo, estão de forma explícita e implícita na execução de uma tarefa (PICHON-RIVIÈRE, 2009). Relacionando com o filme, Doze homens e uma sentença (LUMET, 1957), pode-se perceber neste sentido, a presença de um grupo operativo pela perspectiva do autor.

Analisando a composição desse grupo com o olhar da prática do estudioso, a estrutura e a função de um grupo, são dadas pelo interjogo de atribuição e assunção de papéis.

RC: 105389

Disponível em: https://www.nucleodoconhecimento.com.br/psicologia/processos-grupais 
Ele cita (PICHON-RIVIĖRE, 2009, p. 173): "Estes representam modelos de comportamentos correspondentes à posição dos indivíduos nessa rede de interações, e estão ligados às expectativas próprias e às dos outros membros do grupo."

Logo no início do filme, a decisão do protagonista, o jurado 8, causou um grande desconforto no grupo. Alguns riram, enquanto outros apenas o encaravam. Outros começaram a questionar e reclamar em voz alta. Todo o grupo naquele momento se voltou para tentar mudar a opinião do jurado 8 , que ia contra aos demais. Nesse momento, é possível traçar um paralelo ao que Pichon-Rivière (2009), ressaltou sobre a tarefa, quando menciona os modelos estereótipos que dificultam a aprendizagem e a comunicação do grupo, tornando-os um obstáculo para a situação de mudança.

Assim, a tarefa consiste na elaboração de duas ansiedades básicas: medo da perda (ansiedade depressiva) das estruturas existentes e medo do ataque (ansiedade paranóide) na nova situação, provindo essa última de novas estruturas nas quais o sujeito se sente inseguro por carência de instrumentação. (PICHON-RIVIĖRE, 2009, p. 173)

Essas duas ansiedades, segundo o autor, coexistem e cooperam, configurando a situação de resistência à mudança. E essa resistência é que o grupo operativo deve superar, em um processo de esclarecimento que vai do explícito ao implícito. É possível ilustrar essa dinâmica com um cone invertido (Figura 1):

RC: 105389

Disponível em: https://www.nucleodoconhecimento.com.br/psicologia/processos-grupais 
Figura 1 - Representação gráfica da operação corretiva em Cone Invertido.

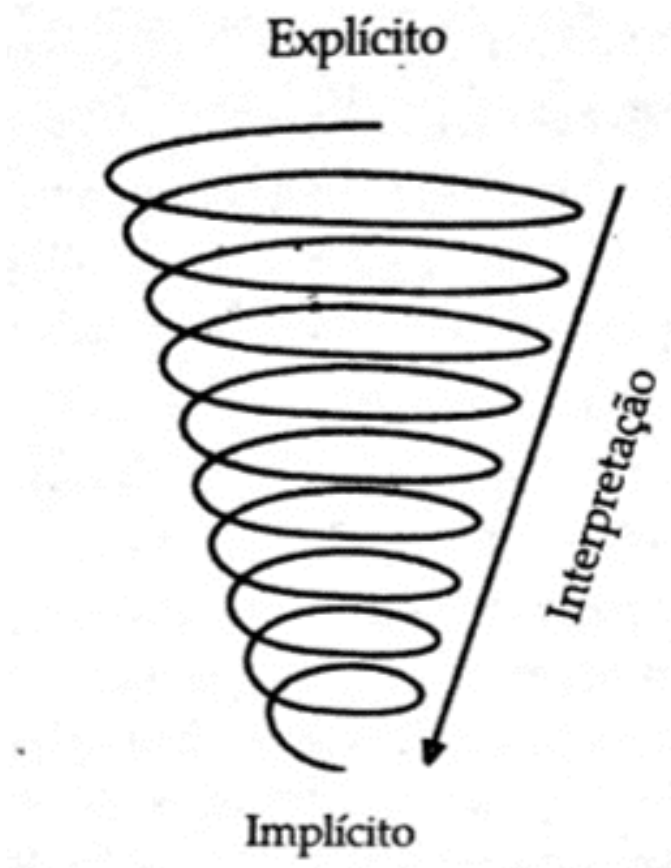

Fonte: (PICHON-RIVIÈRE, 2009, p. 278)

No filme, é possível perceber essas duas ansiedades. Os jurados que votaram no réu como culpado, encaravam o jurado 8 como um lunático. Os questionamentos voltados para o protagonista eram uma mistura de raiva, medo e insegurança. Pichon-Rivière (2009) afirma que no grupo operativo existem papéis que os integrantes assumem que são importantes para a realização da tarefa, e que serão descritos a seguir:

O porta-voz: o porta-voz no grupo é o integrante que diz algo em que se torna o sinal de um processo grupal que, até um determinado momento, permanecia latente, como se estivesse escondido no interior da totalidade do grupo. Nesse sentido, deve ser decodificado e retirar o aspecto implícito (PICHON-RIVIĖRE, 2009). Nesse papel pode-se dizer que o jurado 8 ao levantar a questão sobre a possibilidade do jovem acusado ser inocente, obriga o grupo a encarar a tarefa explícita de modo crítico, deixando de lado os estereótipos de cada um.

RC: 105389

Disponível em: https://www.nucleodoconhecimento.com.br/psicologia/processos-grupais 
O coordenador: o coordenador cumpre o papel de intervir e ajudar os membros do grupo a refletirem, passando pelo obstáculo epistemológico, configurado pelas ansiedades básicas. Ele opera no campo das dificuldades da tarefa e da rede de comunicações, sempre direcionando o grupo para a tarefa comum (PICHONRIVIÈRE, 2009). Desta forma, o jurado 1 (o presidente), ilustra bem esse papel ao longo do filme, já que ele se torna o responsável por organizar as votações, sempre direcionando os jurados para ficarem atentos na tarefa, ouvindo todos e intervindo em momentos pontuais.

O observador: o observador geralmente não é um participante e a sua função é recolher todo o material, expresso verbalmente e pré-verbalmente no grupo. Ele tem o objetivo de realimentar o coordenador no reajuste das técnicas de condução (PICHON-RIVIÈRE, 2009). Pode-se considerar o representante que fica ao lado de fora da sala, como um papel semelhante do observador, já que ele não participa do grupo, mas ajuda trazendo as evidências que o coordenador (jurado 1) solicita durante a tarefa.

O bode expiatório: o bode expiatório é um membro do grupo que acaba recebendo todos os aspectos negativos do grupo ou da tarefa. aparecem assim, os mecanismos de segregação (PICHON-RIVIĖRE, 2009). Em determinados momentos, o jurado 3 tornou-se o bode expiatório do grupo, sendo ele o último a mudar o seu voto, e até por estar extremamente concentrado ao seu ECRO individual. Mas, ao longo do filme, outros jurados assumiram esse papel por um período, como, por exemplo, o jurado 10 , que ao falar sobre essa gente, referindo-se aos moradores de periferias, foi sendo deixado sozinho e ignorado pelos demais que se afastaram como forma de protesto.

O líder: o líder, ao contrário do bode expiatório, é o membro que recebe todos os aspectos positivos do grupo e da tarefa (PICHON-RIVIĖRE, 2009). Pode-se dizer que o protagonista (jurado 8), também ao longo do filme assumiu o papel de líder, ao ponto de conseguir fazer todos os onze jurados mudarem o seu voto ao conquistar a atenção

RC: 105389

Disponível em: https://www.nucleodoconhecimento.com.br/psicologia/processos-grupais 
e a credibilidade de cada um, levando-os a se questionarem sobre as certezas do caso.

É importante ressaltar que, o papel do bode expiatório e do líder estão ligados justamente porque o primeiro surge como um modo de preservar a liderança e através de um processo de dissociação necessário ao grupo na tarefa de discriminação. Portanto, a partir da constatação de certos fenômenos grupais, Pichon-Rivière (2009), constrói uma escala de avaliação básica, devido a classificação de modelos de comportamento grupal (Figura 2).

Figura 2 - Representação gráfica do Esquema do Cone Invertido.

\section{Esquema do cone invertido}

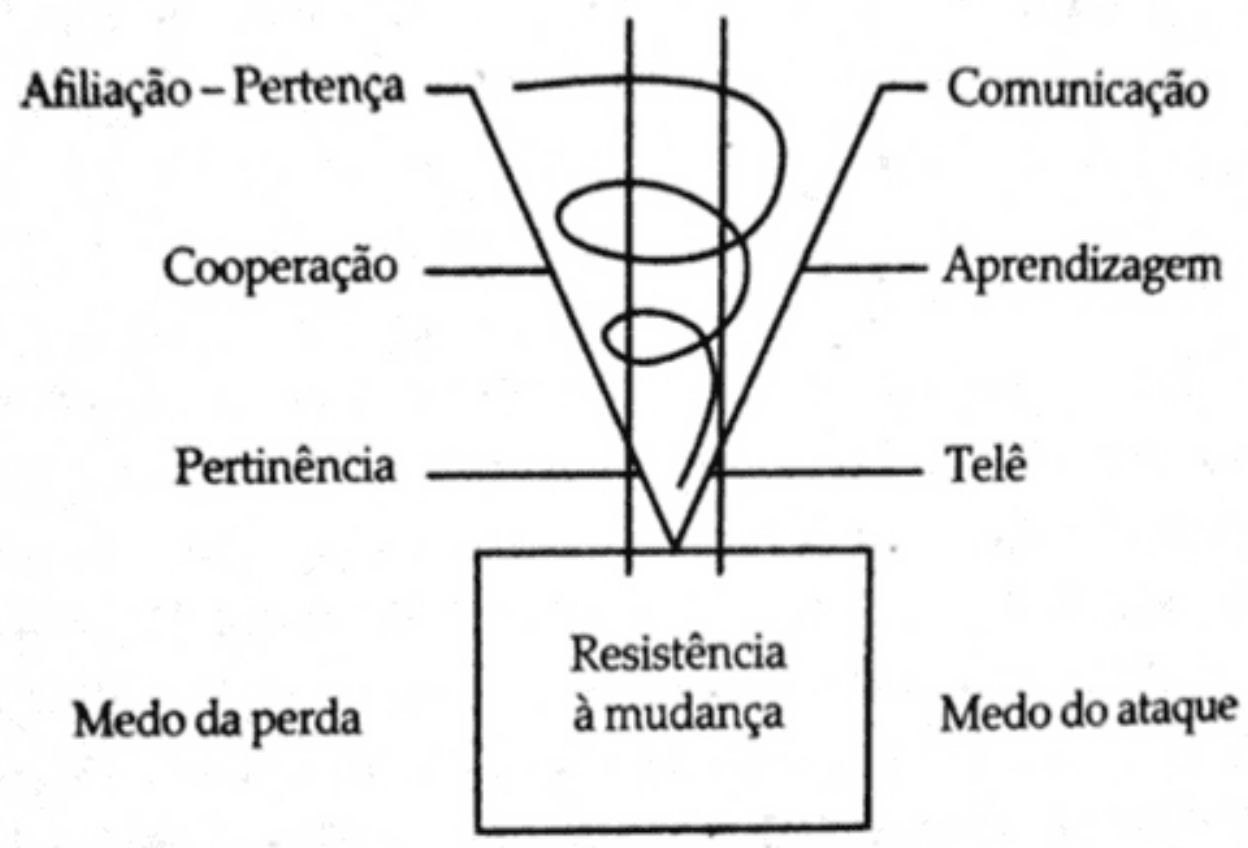

Fonte: (PICHON-RIVIÈRE, 2009, p. 268)

Afiliação ou identificação: o sujeito guarda uma certa distância, sem se incluir de forma completa no grupo. esse primeiro momento depois se transforma em pertença

RC: 105389

Disponível em: https://www.nucleodoconhecimento.com.br/psicologia/processos-grupais 
(PICHON-RIVIÈRE, 2009). Isto é observado quando todos os jurados no início do filme acabam representando o vetor de afiliação, não querendo discutir sobre o caso e tentando finalizar rapidamente a tarefa. Um exemplo é o jurado 5 , que ao chegar a sua vez de explicar o porquê acreditava que o réu era culpado, pediu para pular a vez, sem querer se incluir na discussão.

Pertença: é o sentimento de pertencer ao grupo, a equipe, em que se vê que há uma identificação maior com os processos do grupo e sua tarefa é realizada com uma intensidade maior. Há uma sensação de segurança que favorece a tarefa. (PICHONRIVIÈRE, 2009)

Cooperação: é o elemento que expressa pela forma como os membros do grupo adquirem pela cooperação, uma mesma direção para realizar a tarefa. Aqui os membros do grupo são cooperadores e cooperam na mesma direção. (PICHONRIVIÈRE, 2009)

Pertinência: é a centralização do grupo na tarefa e em seu esclarecimento (PICHONRIVIĖRE, 2009). Isso surge no terceiro ato do filme, em que todos os jurados estavam participando de alguma forma, analisando de modo criterioso o caso, fazendo simulações e colhendo detalhes para justificar ou não o voto dado. Assim, pode-se considerar que estavam em um momento de pertença, e, logo depois, em cooperação para a realização da tarefa.

Comunicação: pode ser verbal ou não verbal, é a comunicação que se dá entre os participantes do grupo.

Neste vetor, levamos em conta não só o conteúdo da mensagem, mas também o como e o quem dessa mensagem; chamamos a isso metacomunicação. Quando os dois elementos entram em contradição, configura-se um mal-entendido dentro do grupo. (PICHON-RIVIĚRE, 2009, p.175)

RC: 105389

Disponível em: https://www.nucleodoconhecimento.com.br/psicologia/processos-grupais 
Aprendizagem: é obtido pela soma das informações dos integrantes, transformando em um dado momento, a quantidade em qualidade, e, assim, produz uma mudança qualitativa no grupo (PICHON-RIVIÈRE, 2009). Durante todo filme a comunicação e a aprendizagem tornaram-se cruciais para a realização da tarefa e a dinâmica do grupo, podendo assim, construir um ECRO grupal.

Telê: vetor definido pelo professor Moreno (apud PICHON-RIVIÈRE, 2009), como uma disposição positiva ou negativa para o trabalho com um membro do grupo.

O fator telê, assim enunciado por J. L. Moreno, psico-socióloogo norteamericano e romeno, residente nos EUA. Segundo Moreno, a telê consiste na capacidade ou disposição que cada um de nós tem para trabalhar com outras pessoas, telê positiva e telê negativa, que darão os fatores afetivos e o clima afetivo. (PICHON-RIVIĖRE, 2009, p. 270)

No filme, existem alguns exemplos, como o jurado 5 com o jurado 10 que tinham uma disposição negativa para atuarem juntos, tendo algumas discussões que acabavam atrapalhando o andamento da tarefa. Já o jurado 8 e o jurado 9 pareciam dispostos positivamente a trabalharem juntos, sendo o jurado 9 o primeiro a mudar o seu voto para inocente, para conseguir, junto com o jurado 8 , investigar melhor o caso antes de condenar o réu à morte.

Além de todos os fatores apresentados pelo autor, é importante ressaltar e distinguir três instâncias dentro do trabalho grupal: a pré-tarefa, a tarefa e o projeto.

Na pré-tarefa estão as técnicas defensivas do grupo, que estruturam a resistência à mudança. Só depois, de passar esse desconforto e quebrar esses estereótipos, podese dizer que o grupo está na tarefa (PICHON-RIVIÈRE, 2009). Logo no início do filme, todos os membros do grupo estavam desconfortáveis com o jurado 8 que foi contra ao veredito de culpado e se atavam na ideia de tentar convencê-lo que estava errado. Presos aos estereótipos, eles se negavam a encarar a tarefa de modo crítico, considerando cada ECRO individual que os impedia de pensar em coletivo.

RC: 105389

Disponível em: https://www.nucleodoconhecimento.com.br/psicologia/processos-grupais 
O momento da tarefa é quando o objeto de conhecimento se torna penetrável. Além disso, ela é a trajetória que o grupo precisa percorrer para atingir os objetivos propostos. É na explicitação do implícito que faz o grupo avançar em direção a tarefa como no movimento de espiral dialética (PICHON-RIVIĖRE, 2009). Esse momento é possível de perceber quando os jurados entram na tarefa e começam a levantar todas as hipóteses, não de modo místico e de certeza de culpa do acusado, mas sim, como possibilidades, fazendo simulações e considerando outros fatores que se não justificam a inocência, também não imprimem a culpa no réu.

Por fim, o projeto ocorre quando o grupo consegue uma pertença dos membros e se concretiza um planejamento (PICHON-RIVIĖRE, 2009). Este ponto encontra-se na conclusão do filme, em que todos os jurados conseguem em comum acordo finalizar a tarefa e dar o veredicto de inocente para o réu, e pode ser mais contextualizado nas palavras do autor na próxima citação:

O grupo se propõe objetivos que ultrapassam o aqui e agora, construindo uma estratégia destinada a alcançar esse objetivo. Mas, dentro desse aqui e agora, podemos interpretar que este projeto, como todo mecanismo de criação, está destinado a superar a situação de morte ou de perda que os membros vivenciam quando, através da realização da tarefa, percebem a possibilidade da separação ou finalização do grupo. (PICHON-RIVIERE, 2009, p. 181)

Por fim, é possível notar que a técnica de grupo operativo criado por Pichon-Rivière (2009) pode ser utilizada em diversas áreas e setores, promovendo um aprendizado e uma mudança significativa aos membros do grupo.

\section{CONSIDERAÇÕES FINAIS}

No artigo apresentado, foram contextualizadas as teorias de Lewin (MAILHIOT, 2013), Moreno (RUSSO, 2010), Schutz (1979; 1989) e Pixon-Rivière (2009), a respeito dos processos de dinâmica de grupo e articulados na análise do filme "Doze homens e Uma Sentença" (LUMET, 1957).

RC: 105389

Disponível em: https://www.nucleodoconhecimento.com.br/psicologia/processos-grupais 
Retomando a questão norteadora: indivíduos com diferenças socioculturais específicas e historicidades divergentes colaboram nos desenvolvimentos psicológicos em processos grupais? Conforme a análise dos quatro teóricos e a sua relação com a dinâmica apresentada no filme, é possível compreender que não é apenas plausível esses desenvolvimentos, mas positivos.

A troca de experiências, mesmo com sujeitos carregados de preconceitos, discriminações e estereótipos pré-concebidos, pode efetivamente resultar em um grande conflito entre os membros em um primeiro momento, afinal, essas construções igualmente mostram conflitos internos que cada indivíduo carrega em sua educação sociocultural. Contudo, são essas relações intergrupais e carregadas com a historicidade de cada membro do grupo, que quando se conduz ao diálogo, debates e interferências de experiências, floresce em amadurecimento por meio da ressignificação e confronto consigo mesmo, sobretudo aqueles carregados de preconceitos e discriminações.

Portanto, o pressuposto da hipótese elaborada pela equipe deste artigo foi confirmado. Indivíduos com históricos antagônicos podem efetivamente contribuir com suas diferentes vivências para a aplicabilidade das técnicas de dinâmica de grupos e amadurecimento dos sujeitos.

As decisões com base no diálogo podem transformar o sujeito e seu próximo. Vale ressaltar que, as experiências vividas por cada indivíduo do grupo ao serem compartilhadas, podem ser melhor entendidas e ressignificadas. Com isso, intui-se que o compartilhamento tem o poder de trazer novas questões e resoluções. Quando um indivíduo vivencia uma experiência particular do outro, pode-se ter uma ação fora do contexto moral e particularizado. Ao olhar, escutar e sentir uma experiência além da cotidiana, é possível criar mais afetividade e empatia com o próximo. Problemas que antes eram vistos como particulares, passaram a ser divididos com um grupo.

RC: 105389

Disponível em: https://www.nucleodoconhecimento.com.br/psicologia/processos-grupais 
Porém, pode-se hoje verificar que uma questão, quando discutida no coletivo, tem a capacidade de gerar resoluções com base na empatia, espontaneidade e criatividade.

Foi possível observar a partir do estudo das teorizações aqui apresentadas, com a dinâmica apresentada no filme de Lumet (1957), que, por mais diferenciados que essas percepções possam ser, a análise de grupos parte da premissa de que os processos grupais vão se transformando a partir das ações dos indivíduos, bem como de suas posições econômicas e culturais. Logo, é de extrema importância o estudo e a compreensão dos processos grupais para os estudantes e profissionais de Psicologia, de forma com que tenham uma compreensão ampla e crítica em sua prática profissional. Em paralelo, todas as teorias dos autores propostos puderam ser observadas com intensidade no filme proposto para análise, tornando o contexto mais compreensível.

A partir do reflexo das vivências humanas através da Arte, pode-se alcançar a compreensão de como as teorias de dinâmica de grupo podem ser aplicadas de forma real, assim como suas várias possibilidades.

\section{REFERÊNCIAS}

BARRETO, Maria Fernanda Mazziotti. Dinâmica de grupo: história, práticas e vivências. 5. ed. Campinas: Alínea, 2014.

FREIRE, Paulo. Justificativa da pedagogia do oprimido. In: Pedagogia do oprimido. 50. ed. Rio de Janeiro: Paz e Terra, 2011.

LANE, Silvia Tatiana Maurer. O Processo Grupal. In: LANE, S.T.M.; CODO, W. (Orgs.) Psicologia social: o homem em movimento. 8. ed. São Paulo: Brasiliense, 1989, p.78-98.

RC: 105389

Disponível em: https://www.nucleodoconhecimento.com.br/psicologia/processos-grupais 
LIMA, Liliana Aparecida de. Psicodrama e Dinâmica de grupo: re-criando possibilidades para o ensino de Psicologia na Universidade. In: BARRETO, Maria Fernanda Mazziotti. Dinâmica de grupo: história, práticas e vivências. 5. ed. Campinas: Alínea, 2014. p. 55-83

LUMET, Sidney. Doze homens e uma sentença (1957) Online. (Twelve Angry Men). Direção de Sidney Lumet. Estados Unidos da América: Metro Goldwyn Mayer, 1957. 95 minutos, inglês, dublado em português, preto e branco. Disponível em: $<$ https://flixfilmes.org/filme/12-homens-e-uma-sentenca-1957-online/>. Acesso em: 05 abr. 2021.

MAILHIOT, Gérald Bernard. Dinâmica e Gênese dos Grupos: atualidade das descobertas de Kurt Lewin. Petrópolis: Vozes, 2013.

MARTINS, Sueli Terezinha Ferreira. Psicologia Social e Processo Grupal: a coerência entre fazer, pensar e sentir em Sílvia Lane. Psicologia \& Sociedade; 19, Edição Especial 2: 76-80, 2007.

MONTERO, Maritza. A tensão entre o fortalecimento e as influências alienadoras no trabalho psicossocial comunitário e político. In: LACERDA, JR; GUZZO, R.S.L. Psicologia \& Sociedade: interfaces no debate sobre a questão social. Campinas: Alínea, 2010. p. 65 - 82.

NERY, Maria da Penha; CONCEIÇÃO, Maria Inês Gandolfo. Sociodrama e política de cotas para negros: um método de intervenção psicológica em temas sociais. Brasília: Psico. cienc. prof., v.25, n.1, março 2005. Disponível em: $<$ https://www.scielo.br/scielo.php?pid=S141498932005000100011\&script=sci_arttext>. Acesso em: 15 abr. 2021.

PICHON-RIVIÈRE, Enrique. O processo grupal. 8. ed. São Paulo: WMF Martins Fontes, 2009.

RC: 105389

Disponível em: https://www.nucleodoconhecimento.com.br/psicologia/processos-grupais 
Rodrigues, Aroldo; Assmar, Eveline Maria Leal; Jablonsky, Bernardo. Psicologia Social. ed. 27. Petrópolis, RJ: Vozes, 2009. p. 147-176.

RUSSO, Luis. Quem sobreviverá?: Fundamentos da sociometria, da psicoterapia de grupo e o sociodrama. Rev. bras. psicodrama, São Paulo, v. 18, n. 2, p. 173188, 2010.

Disponível

em:

$<$ http://pepsic.bvsalud.org/scielo.php?script=sci_arttext\&pid=S0104-

$53932010000200011 \&$ lng=pt\&nrm=iso>. Acesso em: 21 abr. 2021.

SCHUTZ, William C. O prazer: expansão da consciência humana. ed. 1. Rio de Janeiro: Imago, 1979. p. 101-105.

. Profunda Simplicidade: uma nova consciência do eu interior. São Paulo: Ágora, 1989. p. 103-113.

SMIRCICH, Linda; MORGAN, Gareth. Leadership: The management of meaning. The Journal of Applied Behavioral Science, v.18, n.3, 1983. p. 257-273. DOI: $10.1177 / 002188638201800303$

TEIXEIRA, Ludimilla Santana; ABREU, Liliane Alcântara de. Os desafios da educação em direitos humanos no século XXI: a contribuição do MUCB no autoconhecimento e desenvolvimento sociopolítico de mulheres através das redes sociais. In: Anais de Artigos Completos do V CIDHCoimbra 2020 - Volume 3 / César Augusto R. Nunes et. al. (orgs.) [et al.] - Campinas / Jundiaí: Editora Brasílica / Edições Brasil / Editora Fibra, 2021. p. 287. ISSN 978-65-89537-03-8. Disponível em: <https://a3ec55aa-1c0f448d-a555-

bf0db2483a45.filesusr.com/ugd/8f3de9_a7f1803236524ca9ab555127967481aa.pdf> . Acesso em: 10 mai. 2021.

VIEIRA, Emanuel Meireles; XIMENES, Verônica Morais. Conscientização: em que interessa este conceito à psicologia. Psicologia e Argumento, Curitiba, v. 26, n. 52,

RC: 105389

Disponível em: https://www.nucleodoconhecimento.com.br/psicologia/processos-grupais 
$\mathrm{p}$

23-33,

2008.

Disponível

em:

<https://www.researchgate.net/publication/324630701_CONSCIENTIZACAO_Em_qu

e_interessa_este_conceito_a_psicologia>. Acesso em: 15 fev. 2020.

Enviado: Julho, 2021.

Aprovado: Janeiro, 2022.

RC: 105389

Disponível em: https://www.nucleodoconhecimento.com.br/psicologia/processos-grupais 